\title{
Pharmacokinetic and pharmacodynamic modeling of sarafloxacin against avian pathogenic Escherichia coli in Muscovy ducks
}

Yang Yu ${ }^{1,2,3}$, Yu Feng Zhou ${ }^{1,2,3}$, Jian Sun ${ }^{1,2,3}$, Wei Shi ${ }^{1,3}$, Xiao Ping Liao ${ }^{1,2,3}$ and Ya Hong Liu ${ }^{1,2,3,4^{*}}$

\begin{abstract}
Background: This study focused on utilizing pharmacokinetics/pharmacodynamics (PK/PD) modeling to optimize therapeutic dosage regimens of sarafloxacin against avian pathogenic Escherichia. coli O78 strain in Muscovy ducks. The ex vivo PK/PD study of sarafloxacin was conducted in Muscovy ducks after intravenous (i.v.) and oral (p.o.) administrations at a single dose of $10 \mathrm{mg} / \mathrm{kg}$ bodyweight (BW). The serum samples were analyzed by reverse phase high-performance liquid chromatography (RP-HPLC) using a fluorescence detection method. Sarafloxacin PK data were analyzed by a non-compartmental method using Winnonlin software.
\end{abstract}

Results: Calculations of the area under the concentration-time curves $\left(\mathrm{AUC}_{0-24 \mathrm{~h}}\right.$ ) were $8.57 \pm 0.59$ and $8.37 \pm 0.29 \mu \mathrm{g} \cdot \mathrm{h} / \mathrm{ml}$ following i.v. and p.o. administration, respectively. Elimination half-lives $\left(t_{1 / 2 \beta}\right)$ were $6.11 \pm 0.99 \mathrm{~h}$ and $8.21 \pm 0.64 \mathrm{~h}$ for i.v. injection and p.o. administration, respectively. The mean in vitro plasma protein binding of sarafloxacin was $39.3 \%$. Integration using the sigmoid $E_{\max }$ model, the mean values of $\mathrm{AUC}_{0-24 \mathrm{~h}} / \mathrm{MIC}$ needed for bacteriostatic, bactericidal and bacterial eradication action were 25.4, 40.6, and $94.4 \mathrm{~h}$, respectively.

Conclusions: Sarafloxacin administered at a $10 \mathrm{mg} / \mathrm{kg}$ dose may be insufficient for treatment of E. coli O78 infections with an MIC equally to or over $0.125 \mu \mathrm{g} / \mathrm{ml}$. Furthermore, higher doses of sarafloxacin are required to minimize antimicrobial resistance considering the MPC theory.

Keywords: Dosage regimens, Muscovy ducks, Mutant prevention concentration, Pharmacokinetics/pharmacodynamics, Sarafloxacin, Avian pathogenic Escherichia Coli

\section{Background}

The minimum inhibitory concentration (MIC) and minimum bactericidal concentration $(\mathrm{MBC})$ were used to evaluate the efficacy of antimicrobial drugs to eradicate the entire pathogen population [1]. The mutant prevention concentration (MPC) has been proposed to evaluate the ability of antimicrobial agents to prevent the emergence of antibacterial resistance [2]. Pharmacokinetics/

\footnotetext{
*Correspondence: lyh@scau.edu.cn

${ }^{1}$ National Risk Assessment Laboratory for Antimicrobial Resistance of Animal Original Bacteria, South China Agricultural University, Guangzhou 510642, China

${ }^{2}$ Guangdong Provincial Key Laboratory of Veterinary Pharmaceutics Development and Safety Evaluation, South China Agricultural University, Guangzhou 510642, China

Full list of author information is available at the end of the article
}

pharmacodynamics (PK/PD) principles may provide an effective way to control the occurrence and dissemination of bacterial resistance [3, 4]. For fluoroquinolones, the $\mathrm{PK} / \mathrm{PD}$ indices are calculated by the ratio of area under the concentration-time curve to MIC (AUC/MIC) and the ratio of peak drug concentration to $\mathrm{MIC}\left(\mathrm{C}_{\max } / \mathrm{MIC}\right)$ $[3,5]$. Recently, the values of AUC/MPC and $C_{\max } / \mathrm{MPC}$ were determined to minimize the occurrence of the antibacterial resistance $[1,6,7]$.

Muscovy ducks are reared for their distinctive taste, high yield of breast meat and low calorie content [8]. Colibacillosis is the most common disease in the poultry industry causing serious death and economic losses worldwide, e.g. in China [9]. Birds infected with Avian pathogenic Escherichia coli (APEC) are more likely to 
develop infectious bursal disease, mycoplasmosis, coccidiosis, Newcastle Disease, infectious bronchitis, and nutritional deficiencies [10]. APEC are responsible for aerosacculitis, polyserositis, pericarditis, yolk sac infection, respiratory tract infection, septicemia and other extra-intestinal diseases in chickens, turkeys, ducks and other avian species [11-13]. Serotype O78 is recognized as one of the most common and prevalent serogrouping of APEC isolates $[11,12]$. E. Coli strains with the O78 serotype are highly pathogenic and commonly exist in poultry industry. Therefore, treatment of colibacillosis caused by APEC O78 demands far more attention in poultry farming. However, current vaccines have poor efficacy, and therapy is mainly based on antimicrobial therapy.

Sarafloxacin, a second generation fluoroquinolone antibiotic exclusively developed for veterinary use, shows excellent antimicrobial activity [14-16], and is mainly used to treat colibacillosis by binding to topoisomerase II in Gram-negative bacteria [17-19]. In the European Union, sarafloxacin was proposed for use in poultry and fish in 1998 [20]; and difloxacin (whose primary metabolite is sarafloxacin) was authorized in 1998 but in the meantime the marketing authorization was withdrawn [21].

Publications have reported the pharmacokinetics of sarafloxacin in several animals and birds [15, 22]; however, few studies focused on the PK/PD modeling of sarafloxacin in Muscovy ducks. The aims of this work are to: 1) study the PK/PD modeling of sarafloxacin; 2) optimize the clinical dosage regimens for treatment of colibacillosis in Muscovy ducks particularly against the E.coli O78 strains; and 3) assess the risks of using sarafloxacin employing the MPC theory.

\section{Methods}

\section{Bacterium and reagents}

The experiments were performed using an APEC O78 strain (identified by a serum agglutination test) isolated from ducks colibacillosis and stored in our laboratory. Phylogenetic grouping of this strain was $\mathrm{B}_{2}$ type and determined by multiplex PCR using specific primers from chuA, yjaA genes and TSPE4.C2 fragment. E. coli ATCC 25922 (China Institute of Veterinary Drug Control, Beijing, China) was used for the quality control purpose. Sarafloxacin was purchased from Unichna Bio-technology of Zhengzhou Co., LTD, Zhengzhou, China.

\section{Animals and experimental design}

Twenty-four healthy Muscovy ducks (purchased from the Jiangcun poultry market in Baiyun district, Guangzhou, China) of 100-120 days old and weighing 2.4-2.6 kg were used. Ducks were fed commercial drug-free food. All ducks were examined daily, adapted well to the environment, and were clinically healthy prior to the study. All protocols were approved by the Animal Research Committees of South China Agricultural University. All experiments were conducted using the guidelines of the American Association for Accreditation of Laboratory Animal Care (AAALAC) [23].

Animals were randomly divided into two groups of 12/group. Feed was eliminated for $12 \mathrm{~h}$ before and $6 \mathrm{~h}$ post-administration. Sarafloxacin $(2.5 \%)$ was injected intravenously into the left brachial vein at $10 \mathrm{mg} / \mathrm{kg}$ body weight $(\mathrm{BW})$. For oral administration, a soluble powder (5\%), was directly administered into the crop at $10 \mathrm{mg} / \mathrm{kg}$ BW. Blood samples were collected from the right brachial vein at $0,5,15,30,45 \mathrm{~min}$, and 1, 1.5, 2, $3,4,6,8,12,16,24,36$ h post-i.v. administration. For p.o. administration, the time points for blood collection were at $0,10,20,30,45 \mathrm{~min}$, and $1,1.5,2,3,4,6,8,12$, $16,24,36 \mathrm{~h}$. The serum samples were obtained by centrifugation at $2000 \mathrm{~g}$ for $10 \mathrm{~min}$ and stored at $-20{ }^{\circ} \mathrm{C}$ until analyses within 2 weeks.

\section{Sarafloxacin analysis}

A total of $0.1 \mathrm{~mL}$ acetonitrile was added into $0.1 \mathrm{~mL}$ of serum sample. The mixture was rigorously vortexed for $1 \mathrm{~min}$, and then centrifuged at 15,000 g for $5 \mathrm{~min}$. The supernatant was filtered through a $0.22 \mu \mathrm{m}$ cellulose membrane, and $10 \mu \mathrm{L}$ were injected into the reverse phase high-performance liquid chromatography (RPHPLC) system. This RP-HPLC includes a 2695 Waters Alliance system (Milford, MA, USA), a HYPERSIL BDS $\mathrm{C}_{18}$ Column (5, USA), and a HYPERS. The mobile phase consisted of acetonitrile and $0.1 \%$ trifluoroacetic acid (29:71, v: v) at $1 \mathrm{~mL} / \mathrm{min}$ flow rate. A Waters 2475 fluorescence detector operated at an excitation wavelength of $280 \mathrm{~nm}$ and an emission wavelength of $460 \mathrm{~nm}$.

The retention time of sarafloxacin in the serum was $4.9 \pm 0.2 \mathrm{~min}$. The standard curve of sarafloxacin was linear in the range of $0.02-10 \mu \mathrm{g} / \mathrm{mL}$ with correlation coefficient $(\mathrm{R})$ of 0.994 . The recovery of sarafloxacin from serum ranged from $96.5 \pm 1.45 \%$ to $104 \pm 0.76 \%$. The limit of detection (LOD) and limit of quantitation (LOQ) were 0.01 and $0.02 \mu \mathrm{g} / \mathrm{mL}$, respectively.

\section{Protein binding}

In vitro protein binding was determined using an ultracentrifugation method [24]. Sarafloxacin was added to blank plasma samples to produce concentrations of 0.1 , 1 and $10 \mu \mathrm{g} / \mathrm{mL}$. After $1 \mathrm{~h}$ incubation at $37^{\circ} \mathrm{C}, 0.5 \mathrm{~mL}$ of each sample was placed in a Microcon YM-10 centrifugal filter device (Millipore, USA), and centrifuged at $1500 \mathrm{~g}$ for $20 \mathrm{~min}$ at $4{ }^{\circ} \mathrm{C}$. Nonspecific binding of the drug to the ultrafiltration membrane was also determined. The drug concentrations in drug-free plasma samples and ultrafiltrate samples were determined as 
described above. The in vitro plasma protein binding of sarafloxacin was calculated using the following equation:

$$
\mathrm{BP} \%=\left[1-\mathrm{C}_{\mathrm{U}} / \mathrm{C}_{\mathrm{T}}\right] \times 100 \%
$$

where $\mathrm{C}_{\mathrm{U}}$ is the concentration in the ultrafiltrate, and $\mathrm{C}_{\mathrm{T}}$ is the total drug concentration.

\section{MIC, MBC and MPC}

The MIC and MBC were determined in both Mueller Hinton Broth (MHB) and drug-free serum using a standard broth micro-dilution method [25]. MPC was determined as previously described with slight modifications [26]. A single colony was grown overnight in $10 \mathrm{~mL} \mathrm{MHB}$, and $1 \mathrm{~mL}$ of this culture was then transferred to $100 \mathrm{~mL}$ MHB for $24 \mathrm{~h}$ incubation. The culture was washed twice with PBS and centrifuged at $4000 \mathrm{~g}$ for $20 \mathrm{~min}$ at $4{ }^{\circ} \mathrm{C}$. The precipitate was re-suspended in $10 \mathrm{~mL}$ of MHB to obtain a $10^{10} \mathrm{CFU} / \mathrm{mL}$ bacterial load. Aliquots of $100 \mu \mathrm{L}$ were re-suspended and applied to MHA plates containing sarafloxacin at concentrations of $1 \times$ to $128 \times$ MIC. MPC was recorded as the lowest concentration that prevented bacterial growth after $72 \mathrm{~h}$ incubation.

\section{Time-killing curves}

In vitro time-killing curve experiments were conducted in MHB and blank serum using drug concentrations ranged from $0.25 \times$ to $16 \times$ MIC. Serum samples obtained at $0,0.5,1,2,4,6,8,12$ and 24 h post-p.o. administration were used to measure the ex vivo time-killing curves. The initial bacterial counts were about $10^{6} \mathrm{CFU} /$ $\mathrm{mL}$. The $50 \mu \mathrm{L}$ aliquot was diluted appropriately, and $100 \mu \mathrm{L}$ of each dilution were applied onto MHA plates at $0,3,6,9$ and $24 \mathrm{~h}$. All agar plates were incubated at $37{ }^{\circ} \mathrm{C}$ for $18 \mathrm{~h}$. The limit of detection (LOD) was $100 \mathrm{CFU} / \mathrm{mL}$.

\section{PK analysis}

Pharmacokinetic data were analyzed using the Winnonlin Program (version 5.1; Pharsight, St. Louis, MO, USA) based on a non-compartmental model. The bioavailability was estimated by the following equation:

$$
\mathrm{F} \%=\mathrm{AUC}_{\mathrm{PO}} / \mathrm{AUC}_{\mathrm{IV}} \times 100 \%
$$

where $\mathrm{AUC}_{\mathrm{PO}}$ is the $\mathrm{AUC}$ after p.o. administration, and $\mathrm{AUC}_{\mathrm{IV}}$ is the AUC after i.v. injection.

\section{PK/PD integration and modeling}

The PK/PD modeling was analyzed by the Sigmoid $E_{\max }$ model of Winnonlin Software. The equation was defined as:

$$
E=E_{\max }-\left(E_{\max }-E_{0}\right) \times C^{N} /\left(C^{N}+E C_{50}{ }^{N}\right)
$$

Where $E$ is the antibacterial effect. $E_{\max }$ is the $\log _{10}$ difference in bacterial counts between 0 and $24 \mathrm{~h}$ in the control sample. $E_{0}$ is the $\log _{10}$ difference in bacterial counts between 0 and $24 \mathrm{~h}$ in the sample containing sarafloxacin when the LOD of $100 \mathrm{CFU} / \mathrm{mL}$ is reached. $C$ is the PK/PD indexes. $\mathrm{EC}_{50}$ is the PK/PD surrogate parameters producing $50 \%$ of the maximal antibacterial. $N$ is the Hill coefficient which describes the slope of the sigmoid curves.

The PK/PD surrogate markers of antibacterial activity, including $\mathrm{C}_{\max } / \mathrm{MIC}, \mathrm{AUC}_{0-24 \mathrm{~h}} / \mathrm{MIC}, \mathrm{C}_{\max } / \mathrm{MPC}$ and $\mathrm{AUC}_{0-24 \mathrm{~h}} / \mathrm{MPC}$, were determined using in vitro $\mathrm{PD}$ data and in vivo $\mathrm{PK}$ values post-i.v. and -p.o. administration of sarafloxacin. In this model, $\mathrm{AUC}_{0-24 \mathrm{~h}} / \mathrm{MIC}$ values were calculated according to the four levels of antibacterial effectiveness: a bacteriostatic action (i.e., no change in colony counts, $E=0$ ), a $50 \%$ reduction in colony counts, a bactericidal action (i.e., a $99.9 \%$ reduction in bacterial counts, $E=-3$ ), and a bacterial elimination effect (i.e., a 99.99\% reduction in bacterial counts, $E=-4$ ) [27].

\section{Evaluation of dosage regimens}

Optimal dosage providing a specific antibacterial effect was calculated using the following equation:

$$
\begin{aligned}
\text { Dose }(\text { per day })= & \mathrm{Cl}_{(\text {per hour })} \times\left(\mathrm{AUC}_{0-24 \mathrm{~h}} / \mathrm{MIC}\right) \\
& \times \mathrm{MIC} /(F \times f u)
\end{aligned}
$$

Where $\mathrm{Cl}$ is the clearance, $\mathrm{AUC}_{0-24 \mathrm{~h}} / \mathrm{MIC}$ is the ratio of the area under serum concentration-time curve over a $24 \mathrm{~h}$ period to MIC value achieved from PK/PD integration, $F$ is the bioavailability, $f u$ is the unbound fraction of sarafloxacin.

\section{Statistical analysis}

The PK and ex vivo PK/PD data are presented as mean \pm SD. All the data are conducted using the SPSS 16.0 software package (SPSS Inc., Chicago, IL).

\section{Results}

\section{Pharmacokinetic profiles}

A Semi-logarithmic plot of serum concentrations of sarafloxacin following i.v. and p.o. administrations is presented in Fig. 1 and PK parameters calculated by Winnonlin using a non-compartmental model are shown in Table 1. Initial drug concentration in serum for i.v. injection was about $7.53 \mu \mathrm{g} / \mathrm{mL}$, and it rapidly decreased to approximately $0.2 \mu \mathrm{g} / \mathrm{mL}$ at $12 \mathrm{~h}$. For oral administration, a rapid absorption, with a time of peak concentration $\left(T_{\max }\right)$ of $0.44 \pm 0.16 \mathrm{~h}$, was observed and the $C_{\max }$ was $2.03 \pm 0.73 \mu \mathrm{g} / \mathrm{mL}$. The half-lives of elimination $\left(t_{1 / 2 \beta}\right)$ were $6.11 \pm 1.97$ and $8.21 \pm 2.31 \mathrm{~h}$ 


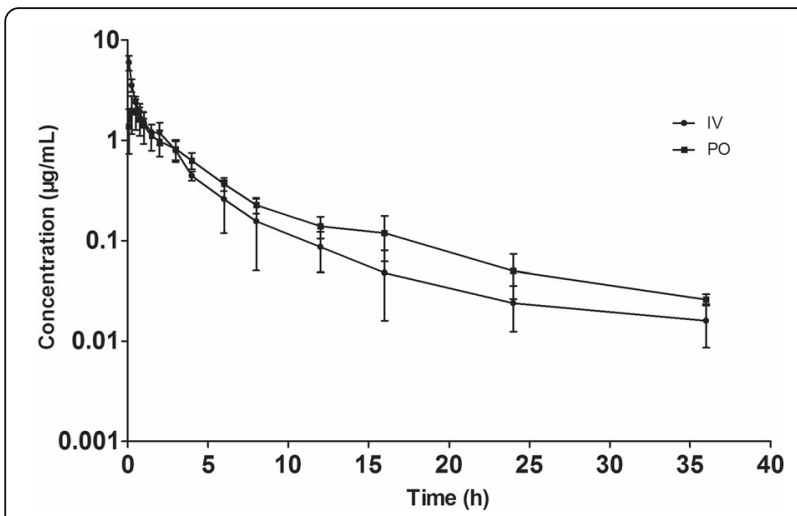

Fig. 1 Semi-logarithmic plot of serum concentrations v.s. time of sarafloxacin in Muscovy ducks $(n=12)$ following a single i.v. and p.o. administration at a single dose of $10 \mathrm{mg} / \mathrm{kg}$ BW. Bars represent standard deviations

following i.v. and p.o. administrations, respectively and the $\mathrm{AUC}_{0-24 \mathrm{~h}}$ were $8.43 \pm 1.06$ and $8.26 \pm 1.08 \mu \mathrm{g} \cdot \mathrm{h} / \mathrm{mL}$, respectively. Bioavailability (F\%) for oral dosing route was $97.6 \pm 5.32 \%$. Drug concentrations of both routes of administration were below the LOD level at $48 \mathrm{~h}$ after a single dose of sarafloxacin in Muscovy ducks.

\section{Protein binding}

The percent of sarafloxacin recovery from ultrafiltration membrane exceeded 95\%, suggesting that the ultrafiltration membrane had no specific adsorption of the drug. Table 2 shows the protein binding rates of sarafloxacin. Bound fraction of sarafloxacin ranged from 24.5 to $56.1 \%$ for drug concentrations varied from 0.1 to $10 \mu \mathrm{g} / \mathrm{mL}$ with a mean binding rate of $39.3 \%$.

Table 1 Pharmacokinetic parameters of sarafloxacin after a single i.v. and p.o. administration at a dose of $10 \mathrm{mg} / \mathrm{kg} \mathrm{BW}$ to Muscovy ducks $(n=12)$ using a non-compartmental model

\begin{tabular}{llll}
\hline Parameter & Unit & IV & $\mathrm{PO}$ \\
\hline $\mathrm{T}_{1 / 2 \beta}$ & $\mathrm{h}$ & $6.11 \pm 1.97$ & $8.21 \pm 2.31$ \\
$\mathrm{~T}_{\max }$ & $\mathrm{h}$ & - & $0.44 \pm 0.16$ \\
$\mathrm{C}_{\max }$ & $\mathrm{\mu g} / \mathrm{mL}$ & - & $2.03 \pm 0.73$ \\
$\mathrm{AUC}_{0-24 \mathrm{~h}}$ & $\mathrm{\mu g} / \mathrm{mL} \cdot \mathrm{h}$ & $8.43 \pm 1.06$ & $8.26 \pm 1.08$ \\
$\mathrm{~V}_{\mathrm{Z}}$ & $\mathrm{L} / \mathrm{kg}$ & $10.4 \pm 3.32$ & - \\
$\mathrm{Cl}$ & $\mathrm{L} / \mathrm{kg} \cdot \mathrm{h}$ & $1.18 \pm 0.16$ & - \\
$\mathrm{V}_{\mathrm{Z}} / \mathrm{F}$ & $\mathrm{L} / \mathrm{kg}$ & - & $14.1 \pm 3.55$ \\
$\mathrm{Cl} / \mathrm{F}$ & $\mathrm{L} / \mathrm{kg} \cdot \mathrm{h}$ & - & $1.21 \pm 0.17$ \\
$\mathrm{MRT} \mathrm{T}_{0-24 \mathrm{~h}}$ & $\mathrm{~h}$ & $4.17 \pm 1.04$ & $7.75 \pm 1.86$ \\
$\mathrm{~F}$ & $\%$ & - & $97.6 \pm 5.32$
\end{tabular}

$T_{1 / 2 \beta}$ elimination half-life, $A \cup C$ area under the curve, $T_{\text {max }}$ time for peak concentration, $C_{\max }$ peak concentration, $V_{Z} / F$ apparent volume of distribution, $C / / F$ overall body clearance, $M R T$ mean residence time, $A U M C$ area under the moment curve, $F$ bioavailability
Table 2 Plasma protein binding of sarafloxacin at three spiked levels

\begin{tabular}{lc}
\hline Spiked levels $(\mu \mathrm{g} / \mathrm{mL})$ & Protein binding rate $(\%)$ \\
\hline 0.1 & $56.1 \pm 4.58$ \\
1 & $37.4 \pm 2.07$ \\
10 & $24.5 \pm 0.90$ \\
\hline
\end{tabular}

\section{MIC, MBC and MPC values}

The MIC, MBC and MPC of sarafloxacin are presented in Table 3. The MPC value for sarafloxacin was $1 \mu \mathrm{g} / \mathrm{mL}$. The ratio of $\mathrm{MBC} / \mathrm{MIC}$ was $2 \mu \mathrm{g} / \mathrm{mL}$ either in $\mathrm{MH}$ broth or in serum, and MPC/MIC value was 8 in $\mathrm{MH}$ broth medium.

\section{Time-killing curves}

In vitro time-killing curves of sarafloxacin against are shown in Fig. 2. Bacterial growth was inhibited obviously at drug concentration at $1 \times$ MIC, but re-growth was observed after $9 \mathrm{~h}$ of incubation. However, the number of bacteria after incubation for $24 \mathrm{~h}$ was still below the initial load. For exposure at drug concentration at $2 \times$ MIC, a bactericidal activity was observed in $24 \mathrm{~h}$, but bacterial cells were not eradicated in the serum samples. When drug concentration was raised from $4 \times$ to $16 \times$ MIC, better antibacterial effectiveness was achieved, showing both bactericidal and eradication effect in $3 \mathrm{~h}$ of incubation.

Figure 3 shows the ex vivo time-killing curves, in which sarafloxacin concentrations in serum samples obtained at $0,0.5,1,2,4,6,8,12$ and $24 \mathrm{~h}$ after p.o. administration were $0,2.22,1.68,1.32,0.75,0.37,0.27$, 0.13 , and $0.04 \mu \mathrm{g} / \mathrm{mL}$, respectively. A rapid bactericidal or elimination action was observed after $3 \mathrm{~h}$ of incubation and no re-growth was seen after $24 \mathrm{~h}$ for all serum samples collected between 0.5 and $6 \mathrm{~h}$. A bacteriostatic action could be observed from serum samples collected at $8 \mathrm{~h}$, whereas the serum sampling at $12 \mathrm{~h}$ and $24 \mathrm{~h}$ exhibited almost non-inhibitory effect.

Table 3 MIC, MBC and MPC values of sarafloxacin against E. coli $\mathrm{O} 78$ in MHB and serum medium

\begin{tabular}{llll}
\hline Parameter & Values $(\mu \mathrm{g} / \mathrm{mL})$ & Parameter & Values $(\mu \mathrm{g} / \mathrm{mL})$ \\
\hline In MH broth & & In serum & \\
MIC & 0.125 & MIC & 0.25 \\
MBC & 0.25 & MBC & 0.5 \\
MPC & 1 & MBC/MIC & 2 \\
MBC/MIC & 2 & & \\
MPC/MIC & 8 & & \\
\hline
\end{tabular}

MIC minimum inhibitory concentration, $M B C$ minimum bactericidal concentration, $M P C$ mutant prevention concentration, $M B C / M I C$ ratio of in vitro $M B C$ to $M I C, M P C /$ MIC ratio of in vitro MPC to MIC 


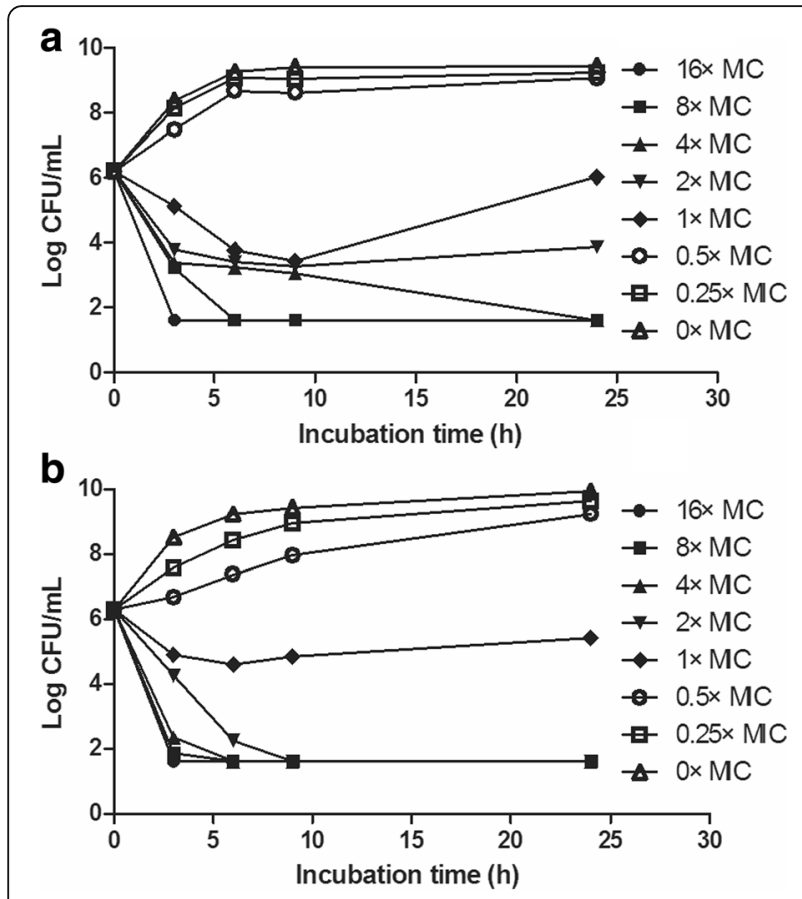

Fig. 2 In vitro time-kill curves of sarafloxacin against the E. coli 078 strain in serum (a) and MHB (b). Numerical values on the right represent sarafloxacin concentrations

\section{PK/PD integration and modeling}

$\mathrm{PK} / \mathrm{PD}$ parameters from the study are summarized in Table 4. The values of $\mathrm{AUC}_{0-24 \mathrm{~h}} / \mathrm{MIC}$ and $\mathrm{C}_{\max } / \mathrm{MIC}$ were $33.4 \pm 4.44 \mathrm{~h}$ and $8.12 \pm 2.92$. Table 5 shows the indexes of PK/PD integration from Sigmoid $\mathrm{E}_{\max }$ model. The relationship between antibacterial effectiveness and $\mathrm{PK} / \mathrm{PD}$ parameter of $\mathrm{AUC}_{0-24 \mathrm{~h}} / \mathrm{MIC}$ is exhibited in Fig. 4. The mean values of $\mathrm{AUC}_{0-24 \mathrm{~h}} / \mathrm{MIC}$ that produced bacteriostatic action, bactericidal activity and bacterial eradication effect were 25.4, 40.6 and 94.5 h, respectively.

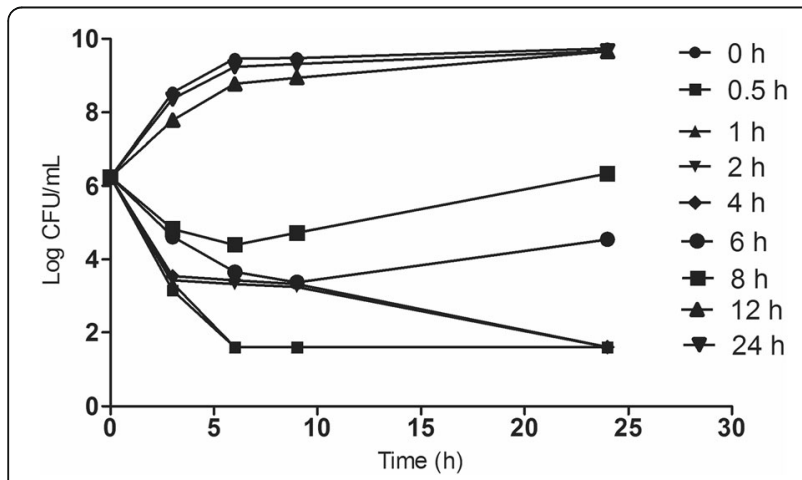

Fig. 3 Ex vivo time-kill curves of sarafloxacin against the E. coli 078 strain after p.o. administration of sarafloxacin at a dose of $10 \mathrm{mg} / \mathrm{kg} \mathrm{BW}$. Values are the means $(n=12)$ and the SD values are excluded for clarity
Table 4 Integration of PK/PD parameters of sarafloxacin against E. coli $\mathrm{O} 78$ after i.v. and p.o. administration $(10 \mathrm{mg} / \mathrm{kg})$ in ducks

\begin{tabular}{lll}
\hline Parameter & IV & PO \\
\hline AUC $_{0-24 \mathrm{~h}} / \mathrm{MIC}(\mathrm{h})$ & $34.3 \pm 4.72$ & $33.5 \pm 4.44$ \\
$\mathrm{C}_{\max } / \mathrm{MIC}$ & - & $8.12 \pm 2.92$ \\
AUC $_{0-24 \mathrm{~h}} / \mathrm{MBC}(\mathrm{h})$ & $17.2 \pm 2.36$ & $16.7 \pm 2.23$ \\
$\mathrm{C}_{\max } / \mathrm{MBC}$ & - & $4.06 \pm 1.45$ \\
AUC & & $8.37 \pm 1.11$ \\
$\mathrm{C}_{\text {max }} / \mathrm{MPC}$ & $8.57 \pm 1.18$ & $2.03 \pm 0.73$ \\
\hline
\end{tabular}

\section{Discussion}

Sarafloxacin MICs in MHB or serum against the E. coli O78 strain used in this study were $0.125 \sim 0.25 \mu \mathrm{g} / \mathrm{mL}$, which is moderate susceptible comparing with previous reports $[14,28]$. In this study, a low ratio of $\mathrm{MBC} / \mathrm{MIC}$ suggests that sarafloxacin has bactericidal activity against the E. coli $\mathrm{O} 78$ strain. In addition, the $\mathrm{MPC} / \mathrm{MIC}$ ratio for sarafloxacin was in agreement with the values calculated for fluoroquinolones from previous reports [29].

In Muscovy ducks, sarafloxacin was rapidly and extensively distributed into body fluids and tissues after i.v. administration. A calculated distribution volume was $10.04 \pm 3.32 \mathrm{~L} / \mathrm{kg}$, which is higher than that in broilers [15]. The $t_{1 / 2 \beta}$ after i.v. injection of sarafloxacin was estimated to be $6.11 \pm 1.97 \mathrm{~h}$, much higher than those reported in pigs and chickens [15], and a slightly higher than that of marbofloxacin in ducks [30]. Therefore, a longer withdrawal time may be required in Muscovy ducks than in other food-producing animals for consideration of residue food safety concerns. A maximum concentration $\left(C_{\max }\right)$ of $2.03 \pm 0.73 \mu \mathrm{g} / \mathrm{mL}$ following p.o. administration of sarafloxacin in this study was observed at $0.44 \pm 0.16 \mathrm{~h}$. Bioavailability was $97.6 \%$ in ducks, which was much higher than the previously reported values of $42.6 \%$ in pigs, $59.6 \%$ in chickens [15], but similar to that of marbofloxacin and moxifloxacin in ducks [30,31], indicating a rapid and

Table 5 Parameters of PK/PD modeling based on ex vivo serum data after p.o. administration of sarafloxacin in muscovy ducks $(n=12)$

\begin{tabular}{lll}
\hline Parameter & Unit & E. coli O78 \\
\hline Log $E_{0}$ & $\mathrm{CFU} / \mathrm{mL}$ & $3.58 \pm 0.27$ \\
Log $E_{0}-$ Log $E_{\max }$ & $\mathrm{CFU} / \mathrm{mL}$ & $8.31 \pm 0.28$ \\
Slope$(\mathrm{N})$ & - & $3.42 \pm 0.15$ \\
$\mathrm{AUC}_{0-24 \mathrm{~h}} / \mathrm{MIC}$ for bacteriostatic action & $\mathrm{h}$ & $25.4 \pm 1.68$ \\
AUC $_{0-24 \mathrm{~h}} / \mathrm{MIC}$ EC & & $27.5 \pm 1.86$ \\
AUC $_{0-24 \mathrm{~h}} / \mathrm{MIC}$ for bactericidal action & $\mathrm{h}$ & $40.6 \pm 2.46$ \\
AUC $_{0-24 \mathrm{~h}} / \mathrm{MIC}$ for bacterial eradication & $\mathrm{h}$ & $94.5 \pm 7.70$
\end{tabular}

$E_{0}$ : difference in bacterial count in control sample between time 0 and $24 \mathrm{~h}$; $E_{\text {max }}$ : difference in bacterial count in sample containing sarafloxacin between time 0 and $24 \mathrm{~h}$, when limit of detection is reached; $N$ : the Hill coefficient; $\mathrm{AUC}_{0-24 \mathrm{~h}} / \mathrm{MIC} \mathrm{EC}_{50}$ : $\mathrm{AUC}_{0-24 \mathrm{~h}} / \mathrm{MIC}$ of drug producing $50 \%$ of the maximum antibacterial effect 


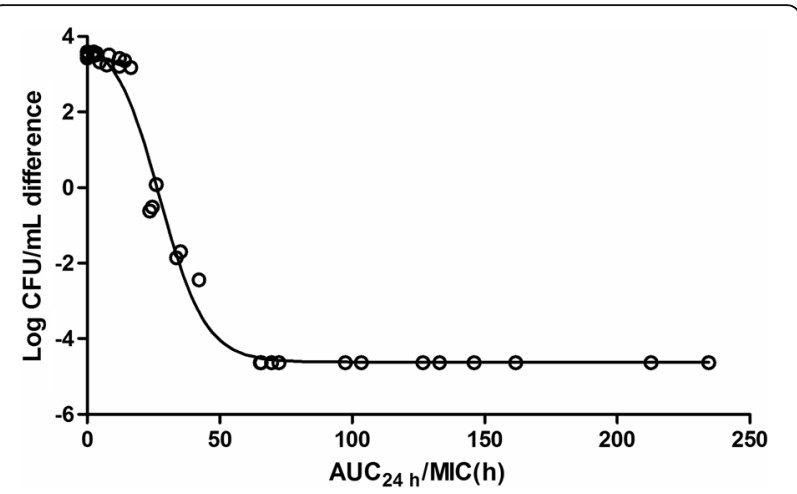

Fig. 4 Plots of the ex vivo $\mathrm{AUC}_{0-24 \mathrm{~h}} / \mathrm{MIC}$ ratios versus the difference of bacterial counts $\left(\log { }_{10} \mathrm{CFU} / \mathrm{mL}\right)$ between 0 and $24 \mathrm{~h}$ for E. coli 078 strain

almost complete absorption following p.o. administration. Total body clearance was $1.18 \mathrm{~L} / \mathrm{kg} / \mathrm{h}$, similarly to that in broilers [15]. The AUCs after i.v. and p.o. administrations were comparable with the results obtained from chickens and pigs [15].

It is recognized that only the unbound fraction of the drug has the antibacterial activity [27]. The plasma protein binding of sarafloxacin was $39.3 \%$, consistent with previous reports [24]. Based on the time-killing curves, antibacterial activity of sarafloxacin against the $E$. coli strains was concentration-dependent. Similar to other fluoroquinolones and aminoglycosides, the ratios of $\mathrm{AUC}_{0-24 \mathrm{~h}} / \mathrm{MIC}$ and $\mathrm{C}_{\text {max }} / \mathrm{MIC}$ were key PK-PD parameters correlating with clinical efficacy in target animals [3]. Attainment target of $\mathrm{AUC}_{0-24 \mathrm{~h}} / \mathrm{MIC}$ of $100-125 \mathrm{~h}$ or $\mathrm{C}_{\max } / \mathrm{MIC}$ of 8-10 should be obtained for fluoroquinolones in order to exert great bacteriological and treatment effects against Gram-negative bacterial pathogens; on the contrary, $\mathrm{AUC}_{0-24 \mathrm{~h}} / \mathrm{MIC}$ of $30 \mathrm{~h}$ should be achieved against Gram-positive pathogens [5, 32, 33]. However, optimal $\mathrm{PK} / \mathrm{PD}$ endpoints for fluoroquinolones were not fixed dependent upon combinations of drug, pathogen and target species, as described in previous reports [16, 28]. Thus, appropriate endpoints of $\mathrm{PK} / \mathrm{PD}$ parameters should be established for specific drug against specific pathogen in given target animal species. In the present study, the values of $\mathrm{AUC}_{0-24 \mathrm{~h}} / \mathrm{MIC}$ theoretically needed for bacteriostatic, bactericidal and eradication activity were calculated using the sigmoid $E_{\max }$ model. The value calculated for eradication activity against the E. coli 078 strain $(94.5 \mathrm{~h}$ ) was smaller than the literature value of $125 \mathrm{~h}$ [32]. At a dosage of $10 \mathrm{mg} / \mathrm{kg} \mathrm{BW}$ administered p.o., the in vivo $\mathrm{AUC}_{0-24 \mathrm{~h}} / \mathrm{MIC}$ ratio for the $E$. coli $\mathrm{O} 78$ strain $(33.5 \mathrm{~h}$ ) was slightly lower than the ex vivo $\mathrm{AUC}_{0-24 \mathrm{~h}} / \mathrm{MIC}$ ratio required for bactericidal action $(40.6 \mathrm{~h})$. These results indicated that the dosage of $10 \mathrm{mg} / \mathrm{kg} \mathrm{BW}$ was not high enough to cure colibacillosis caused by E. coli O78 (MIC = $0.125 \mu \mathrm{g} / \mathrm{mL}$ ). Thus, daily dosage regimens for sarafloxacin following p.o. administration to achieve bacteriostatic, bactericidal and eradicaton effects were calculated as 6.30, 10.1 and $23.6 \mathrm{mg} / \mathrm{kg} \mathrm{BW}$, respectively for dose optimization. Considering that sarafloxacin is concentration dependent antibiotic and convenience of clinical application, single dose administration daily is recommended.

As described in other previous reports [1, 6, 7], the MPC theory is also taken into consideration when optimizing the sarafloxacin dosage regimens in ducks. Traditional PK/PD modeling regards $\mathrm{MIC}$ and $\mathrm{MBC}$ as the major PD parameters; however, they may have only considered antibacterial activity against pathogenic population [1]. With the increasing of antimicrobial resistance, the MPC and mutant prevention window (MSW, defined as the concentration range between MIC and MPC in which the resistant mutants are selectively enriched [2]) have been used to evaluate antibacterial activity to prevent selection and development of antibacterial resistant mutants. The new PK/PD parameters, including $\mathrm{AUC}_{0-24 \mathrm{~h}} /$ MPC, $C_{\max } / \mathrm{MPC}$ and $\mathrm{T}>\mathrm{MPC}$, were used for the optimization of dosage regimens in the current study. In this study the values of $\mathrm{AUC}_{0-24 \mathrm{~h}} / \mathrm{MPC}$ and $\mathrm{C}_{\max }$ / MPC (8.37 $\mathrm{h}$ and 2.03, respectively) for sarafloxacin against the E. coli $\mathrm{O} 78$ strain were comparable to the values (9.76 $\mathrm{h}$ and 1.26) obtained for enrofloxacin against Pasteurella multocida in buffalo calves [1] and the values (9.70 $\mathrm{h}$ and 1.40) obtained for marbofloxacin against E. coli [34]. According to previous reports, the values of $\mathrm{AUC}_{0-24 \mathrm{~h}} / \mathrm{MPC}$ of 9 to $12 \mathrm{~h}$ could prevent occurrence of resistant mutants for marbofloxacin against E. coli [35], which means average plasma concentration being $37.5 \sim 50 \%$ of MPC value can achieve a efficacy of preventing resistant mutants based on the dimensional perspective of AUC/MIC theory [36]. In order to cure diseased animals and control selection and development of drug resistance, the drug concentration in serum should exceed the MPC value as long as possible [7]. In this study, the value of $\mathrm{T}>\mathrm{MPC}$ for sarafloxacin was $1.85 \mathrm{~h}$, which was short due to high MPC. Similarly, $\mathrm{AUC}_{0-24 \mathrm{~h}} / \mathrm{MPC}$ and $\mathrm{C}_{\max } / \mathrm{MPC}$ from this study were lower than the values reported in literature for preventing the selection of resistant mutants. Therefore, the AUC/MPC of $8.37 \mathrm{~h}$ of sarafloxacin may be insufficient for preventing resistant mutant in the current work. Further study is needed to better understand the PK/PD characteristic for sarafloxacin, considering the interaction of drugs, pathogens and animal species.

\section{Conclusions}

To our knowledge, it is the first report about the PK/PD modeling study for sarafloxacin in Muscovy ducks targeting avian pathogenic E. coli O78 strain. Ex vivo PK/PD modeling and the MPC theory were used to optimize reasonable dosage regimens. Our 
findings suggested that a single dose of $10 \mathrm{mg} / \mathrm{kg}$ BW administered orally is insufficient to treat infection caused by E. coli $\mathrm{O} 78$ with an MIC of 0.125 or higher. In addition, a higher dose of sarafloxacin is needed to minimize occurrence of antimicrobial resistance with consideration of MPC theory.

\section{Abbreviations}

i.v.: Intravenous; LOD: Limit of detection; LOQ: Limit of quantification; MBC: Minimal bactericidal concentration; MIC: Minimal inhibitory concentration; MPC: Mutant prevention concentration; p.o.: Per os; PK PD: Pharmacokinetics and pharmacodynemics

\section{Acknowledgements}

None.

\section{Funding}

This study was supported by Program for Changjiang Scholars and Innovative Research Team in University of Ministry of Education of China (Grant No. IRT13063) and the National Key Research and Development Program of China (2016YFD0501310).

\section{Availability of data and materials}

The datasets used and/or analyzed during the current study are available from the corresponding author on reasonable request.

\section{Authors' contributions}

$Y L, Y Z$ and WS designed and conducted the experiment. JS and $X L$ ran the simulations and analyzed the resulting data. $Y Y$ drafted the manuscript. All authors read, revised, and approved the final manuscript.

\section{Competing interests}

The authors declare that they have no competing interests.

\section{Consent for publication}

Not applicable.

\section{Ethics approval}

This study was approved by the Animal Research Committees of South China Agricultural University. All experiments were conducted using the guidelines of the American Association for Accreditation of Laboratory Animal Care (AAALAC)

\section{Author details}

${ }^{1}$ National Risk Assessment Laboratory for Antimicrobial Resistance of Anima Original Bacteria, South China Agricultural University, Guangzhou 510642, China. ${ }^{2}$ Guangdong Provincial Key Laboratory of Veterinary Pharmaceutics Development and Safety Evaluation, South China Agricultural University, Guangzhou 510642, China. ${ }^{3}$ Laboratory of Veterinary Pharmacology, College of Veterinary Medicine, South China Agricultural University, Guangzhou, Guangdong 510642, China. ${ }^{4}$ College of Veterinary Medicine, National Reference Laboratory of Veterinary Drug Residues, South China Agricultural University, Guangzhou 510642, China.

Received: 23 November 2016 Accepted: 1 February 2017 Published online: 10 February 2017

\section{References}

1. Balaje RM, Sidhu PK, Kaur G, Rampal S. Mutant prevention concentration and PK-PD relationships of enrofloxacin for Pasteurella multocida in buffalo calves. Res Vet Sci. 2013;95(3):1114-24.

2. Drlica K. The mutant selection window and antimicrobial resistance. J Antimicrob Chemother. 2003:52(1):11-7.

3. Craig WA. Pharmacokinetic/pharmacodynamic parameters: rationale for antibacterial dosing of mice and men. Clin Infect Dis. 1998;26(1):1-10. quiz 11-12.

4. Drusano GL. Prevention of resistance: a goal for dose selection for antimicrobial agents. Clin Infect Dis. 2003:36 Suppl 1:S42-50.

5. Toutain PL, del Castillo JR, Bousquet-Melou A. The pharmacokineticpharmacodynamic approach to a rational dosage regimen for antibiotics. Res Vet Sci. 2002;73(2):105-14.
6. Liang B, Bai N, Cai Y, Wang R, Drlica K, Zhao X. Mutant prevention concentrationbased pharmacokinetic/pharmacodynamic indices as dosing targets for suppressing the enrichment of levofloxacin-resistant subpopulations of Staphylococcus aureus. Antimicrob Agents Chemother. 2011;55(5):2409-12.

7. Xu L, Wang H, Yang X, Lu L. Integrated pharmacokinetics/pharmacodynamics parameters-based dosing guidelines of enrofloxacin in grass carp Ctenopharyngodon idella to minimize selection of drug resistance. BMC Vet Res. 2013:9:126.

8. Zeng T, Jiang X, Li J, Wang D, Li G, Lu L, Wang G. Comparative proteomic analysis of the hepatic response to heat stress in Muscovy and Pekin ducks: insight into thermal tolerance related to energy metabolism. PLoS One. 2013;8(10):e76917

9. Zhuang QY, Wang SC, Li JP, Liu D, Liu S, Jiang WM, Chen JM. A clinical survey of common avian infectious diseases in China. Avian Dis. 2014;58(2):297-302.

10. La Ragione RM, Sayers AR, Woodward MJ. The role of fimbriae and flagella in the colonization, invasion and persistence of Escherichia coli 078 : K80 in the day-old-chick model. Epidemiol Infect. 2000;124(3):351-363.

11. Dho-Moulin M, Fairbrother JM. Avian pathogenic Escherichia coli (APEC) Vet Res. 1999:30(2-3):299-316.

12. Ewers C, Janssen T, Wieler LH. Avian pathogenic Escherichia coli (APEC). Berl Munch Tierarztl Wochenschr. 2003:116(9-10):381-95.

13. Lutful Kabir SM. Avian colibacillosis and salmonellosis: a closer look at epidemiology, pathogenesis, diagnosis, control and public health concerns. Int J Environ Res Public Health. 2010;7(1):89-114

14. Jones RN, Erwin ME. In vitro susceptibility testing and quality control parameters for sarafloxacin (a-56620): a fluoroquinolone used for treatment and control of colibacillosis in poultry. Quality control study group. Diagn Microbiol Infect Dis. 1998:32(1):55-64.

15. Ding HZ, Zeng ZL, Fung KF, Chen ZL, Qiao GL. Pharmacokinetics of sarafloxacin in pigs and broilers following intravenous, intramuscular, and oral single-dose applications. J Vet Pharmacol Ther. 2001;24(5):303-8.

16. Aliabadi FS, Lees P. Pharmacokinetics and pharmacokinetic/ pharmacodynamic integration of marbofloxacin in calf serum, exudate and transudate. J Vet Pharmacol Ther. 2002:25(3):161-74.

17. Parshikov IA, Freeman JP, Lay Jr JO, Moody JD, Williams AJ, Beger RD, Sutherland JB. Metabolism of the veterinary fluoroquinolone sarafloxacin by the fungus Mucor ramannianus. J Ind Microbiol Biotechnol. 2001;26(3):140-4.

18. Haritova AM, Rusenova NV, Parvanov PR, Lashev LD, Fink-Gremmels J. Pharmacokinetic-pharmacodynamic modelling of danofloxacin in turkeys. Vet Res Commun. 2006;30(7):775-89.

19. Walker RD. The use of fluoroquinolones for companion animal antimicrobial therapy. Aust Vet J. 2000;78(2):84-90.

20. Products TEAftEoM, Unit VME: Committee for veterinary medicinal products saraflocaxin (Salmonidae) Summary Report (2). 1998, EMEA/MRL/349/98FINAL February 1998.

21. The European Agency for the Evaluation of Medicinal Products Veterinary Medicines and Inspections. http://www.ema.europa.eu/docs/en_GB/ document_library/EPAR_-_Scientific_Discussion/veterinary/000031/ WC500062807.pdf. Accessed 14 Dec 2008.

22. Ho SP, Cheng CF, Wang WS. Pharmacokinetic and depletion studies of sarafloxacin after oral administration to eel (Anguilla anguilla). J Vet Med Sci. 1999;61(5):459-63.

23. Institute of Laboratory Animal Research CoLS, Council. NR. Guide for the care and use of laboratory animals. Washington, DC: National Academy Press; 1996.

24. Illambas J, Potter T, Cheng Z, Rycroft A, Fishwick J, Lees P. Pharmacodynamics of marbofloxacin for calf pneumonia pathogens. Res Vet Sci. 2013;94(3):675-81.

25. CLSI: Performance Standards for Antimicrobial Disk and Dilution Susceptibility Tests for Bacterial Isolated from Animals; Approved StandardFourth Edition and Supplement, VET01A4E and VET01S2E PA: Clinical and Laboratory Standards Institute 2013

26. Marcusson LL, Olofsson SK, Komp Lindgren P, Cars O, Hughes D. Mutant prevention concentrations of ciprofloxacin for urinary tract infection isolates of Escherichia coli. J Antimicrob Chemother. 2005;55(6):938-43.

27. Elias G, Lee JS, Hwang MH, Park YS, Cho KH, Kim YH, Park SC. Pharmacokinetics and pharmacokinetic/pharmacodynamic integration of orbifloxacin in Korean Hanwoo cattle. J Vet Pharmacol Ther. 2009;32(3):219-28.

28. Gebru E, Lee JS, Chang ZQ, Hwang MH, Cheng H, Park SC. Integration of pharmacokinetic and pharmacodynamic indices of orbifloxacin in beagle dogs after a single intravenous and intramuscular administration. Antimicrob Agents Chemother. 2009;53(7):3024-9. 
29. Linde HJ, Lehn N. Mutant prevention concentration of nalidixic acid, ciprofloxacin, clinafloxacin, levofloxacin, norfloxacin, ofloxacin, sparfloxacin or trovafloxacin for Escherichia coli under different growth conditions. J Antimicrob Chemother. 2004:53(2):252-7.

30. Yuan L, Wang R, Sun L, Zhu L, Luo X, Sun J, Fang B, Liu Y. Pharmacokinetics of marbofloxacin in Muscovy ducks (Cairina moschata). J Vet Pharmacol Ther. 2011;34(1):82-5.

31. Goudah A, Hasabelnaby S. Pharmacokinetics, plasma protein binding and bioavailability of moxifloxacin in Muscovy ducks after different routes of administration. Res Vet Sci. 2010;88(3):507-11.

32. Lees $\mathrm{P}$, Aliabadi FS. Rationalising dosage regimens of antimicrobial drugs: a pharmacological perspective. J Med Microbiol. 2000;49(11):943-5.

33. Papich MG. Pharmacokinetic-pharmacodynamic (PK-PD) modeling and the rational selection of dosage regimes for the prudent use of antimicrobial drugs. Vet Microbiol. 2014:171(3-4):480-6.

34. Gebru E, Choi MJ, Lee SJ, Damte D, Park SC. Mutant-prevention concentration and mechanism of resistance in clinical isolates and enrofloxacin/marbofloxacinselected mutants of Escherichia coli of canine origin. J Med Microbiol. 2011;60(Pt 10):1512-22.

35. Ferran A, Dupouy V, Toutain PL, Bousquet-Melou A. Influence of inoculum size on the selection of resistant mutants of Escherichia coli in relation to mutant prevention concentrations of marbofloxacin. Antimicrob Agents Chemother. 2007;51(11):4163-6.

36. Toutain PL, Bousquet-Melou A, Martinez M. AUC/MIC: a PK/PD index for antibiotics with a time dimension or simply a dimensionless scoring factor? J Antimicrob Chemother. 2007;60(6):1185-8.

\section{Submit your next manuscript to BioMed Central and we will help you at every step:}

- We accept pre-submission inquiries

- Our selector tool helps you to find the most relevant journal

- We provide round the clock customer support

- Convenient online submission

- Thorough peer review

- Inclusion in PubMed and all major indexing services

- Maximum visibility for your research

Submit your manuscript at www.biomedcentral.com/submit

) Biomed Central 